\title{
Viola silicestris, a new species in Viola section Erpetion from Australia
}

\author{
Kevin R. Thiele* and Suzanne M. Prober \\ Centre for Plant Biodiversity Research, CSIRO, GPO Box 1600, Canberra, ACT 2601 \\ ${ }^{\star}$ Author for correspondence
}

\begin{abstract}
Viola silicestris, a distinctive new species found in sandstone and rhyolite habitats in eastern New South Wales and far south-eastern Queensland, is described. It has previously been confused with Viola sieberiana and $V$. hederacea, from which it differs in habit, leaf, flower and habitat characters.
\end{abstract}

\section{Introduction}

Viola section Erpetion (Sweet) Benth. \& Hook.f. comprises c. 12 taxa of endemic Australian violets, and constitutes the majority of the Australian species of Viola. Ongoing studies of members of the section are helping to resolve species boundaries in what has traditionally been regarded as a difficult group, resulting in the description of a number of new species (see Thiele \& Prober, 2003). The present paper describes Viola silicestris, a distinctive new species from sandstone and rhyolitic habitats on the coast and ranges of New South Wales and south-eastern Queensland.

Viola silicestris K.R.Thiele \& Prober sp. nov.

Affinis Viola sieberiana Spreng. sed foliis plerumque latioribus, basi late cuneata, et dentibus minoribus aequioribusque differt. Affinis Viola hederacea Labill. sed foliis latioribus, floribus concoloribus, pallide caeruleo-violaceis, glandibus antherarum angusto-sinuatis, et seminibus atro-purpureis differt.

Type: Australia, New South Wales, Carrington Falls, 3 Jan 1998, K.R.Thiele 2568 \& S.M. Prober (Holo: CANB; Iso: MEL, NSW, BRI)

Perennial herb spreading by stolons; rootstock not or scarcely swollen at the stem bases, with a slender, \pm woody taproot. Stems varying from contracted so that the leaves form rosettes (in exposed plants) to elongate and scrambling to $0.4 \mathrm{~m}$ high with caulescent leaves (in sheltered plants). Leaves broad, the largest (4-)6-10(-15) $\mathrm{mm}$ long, (5-)10-25(-38) mm wide, (1-)2-4(-5) times wider than long, usually truncate at base (the basal angle c. $180^{\circ}$ ), occasionally sub-reniform or \pm tapering; lamina with (5-) 7-12(-14) obscure teeth, the apical tooth not prominently larger than the rest, glabrous or occasionally sparsely short-pubescent when young, green above and beneath; petioles 2-11 cm long; stipules scarious, narrowly triangular with several irregular, elongate, 


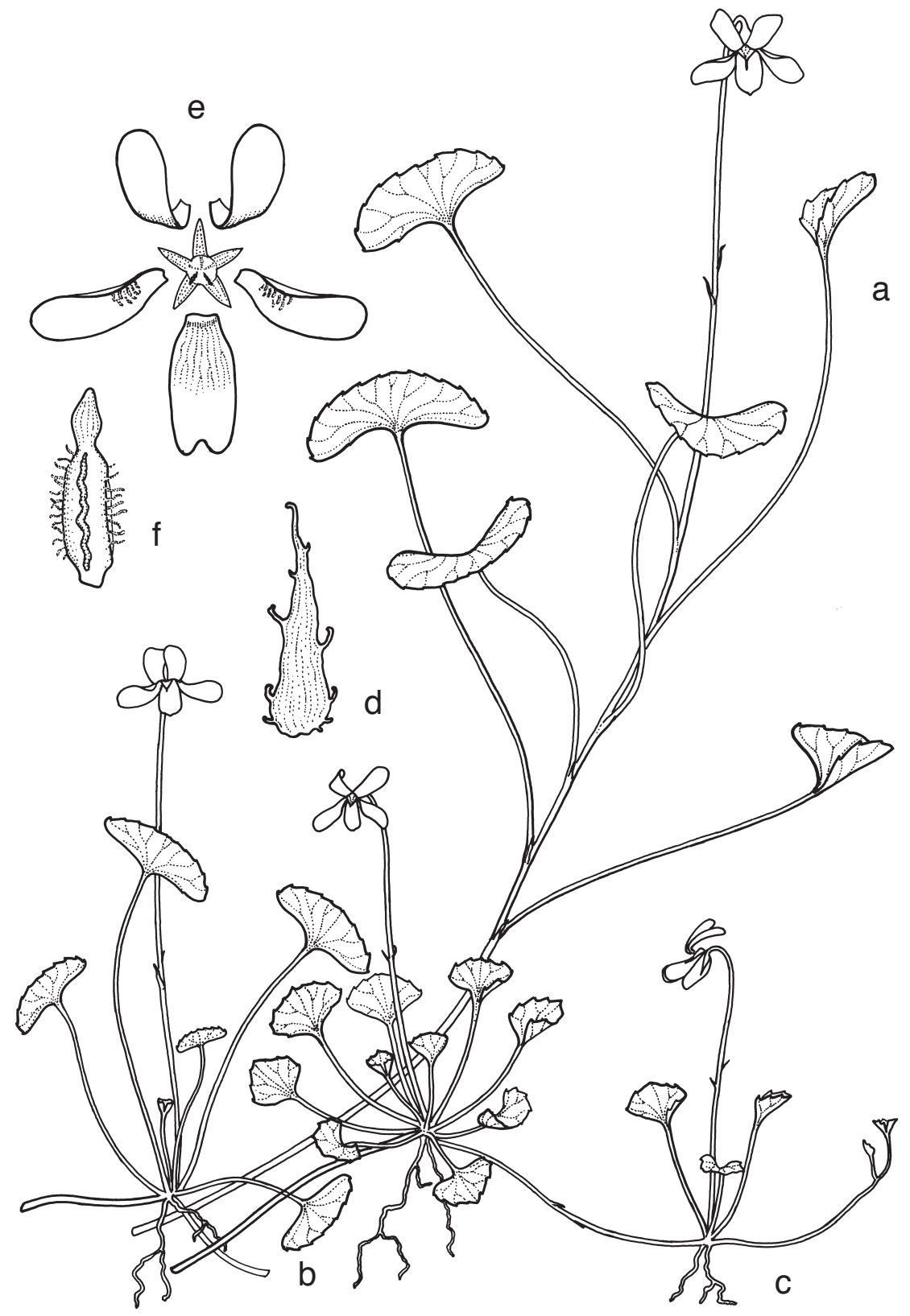

Fig. 1. Viola silicestris. $\mathbf{a}-\mathbf{c}$, habit $\times 1$. a, caulescent plant from sheltered site; $\mathbf{b}$, non-caulescent plant from sheltered site; $\mathbf{c}$, non-caulescent, small-leaved plant from exposed site; d, Stipule $\times 5$; e, Flower $\times 4$; f, Ventral anther showing gland $\times 10$. (K.R. Thiele 2542, CANB). 
glandular teeth on each side. Flowers prominently displayed, on scapes longer than the leaves, concolorous pale mauve-blue (rarely somewhat discolorous); anterior petal (5-)6-7(-8) mm long, 3-4 mm wide, \pm rectangular to ovate, usually emarginate, with a small green blotch at the base then concolorous or with a whitish base, without a white apex, \pm regularly triplinerved with darker veins ; lateral petals spreading, 6-8 $\mathrm{mm}$ long, twisted usually to c. $90^{\circ}$ and usually reflexed, concolorous; beard absent or present, comprising pale hairs; dorsal petals 6-7 $\mathrm{mm}$ long, 2-3 $\mathrm{mm}$ wide, narrowly obovate, erect to reflexed, concolorous. Anthers $1.5-2.5 \mathrm{~mm}$ long, violet-tinted, the terminal appendages straw-coloured, with short, irregular hairs on the outer margins of the anther cells; anther glands pale, slightly shorter than the anther cells, irregular, narrow; pollen and interior margins of the anther cells pale cream. Ovary and fruit pale green with or without purple spots or blotches; style distinctly kinked at its insertion on the ovary. Seeds 1.5-1.7 mm long, glossy purplish-black when mature. Figure 1.

Derivation of name: from the Latin silice (silica), and -estris (inhabiting), in reference to the characteristic occurrence on siliceous, sandy soils.

Suggested common name: Sandstone Violet

Distribution and habitat: Viola silicestris occurs in scattered localities on the coast and Great Dividing Range in eastern New South Wales and far south-eastern Queensland.

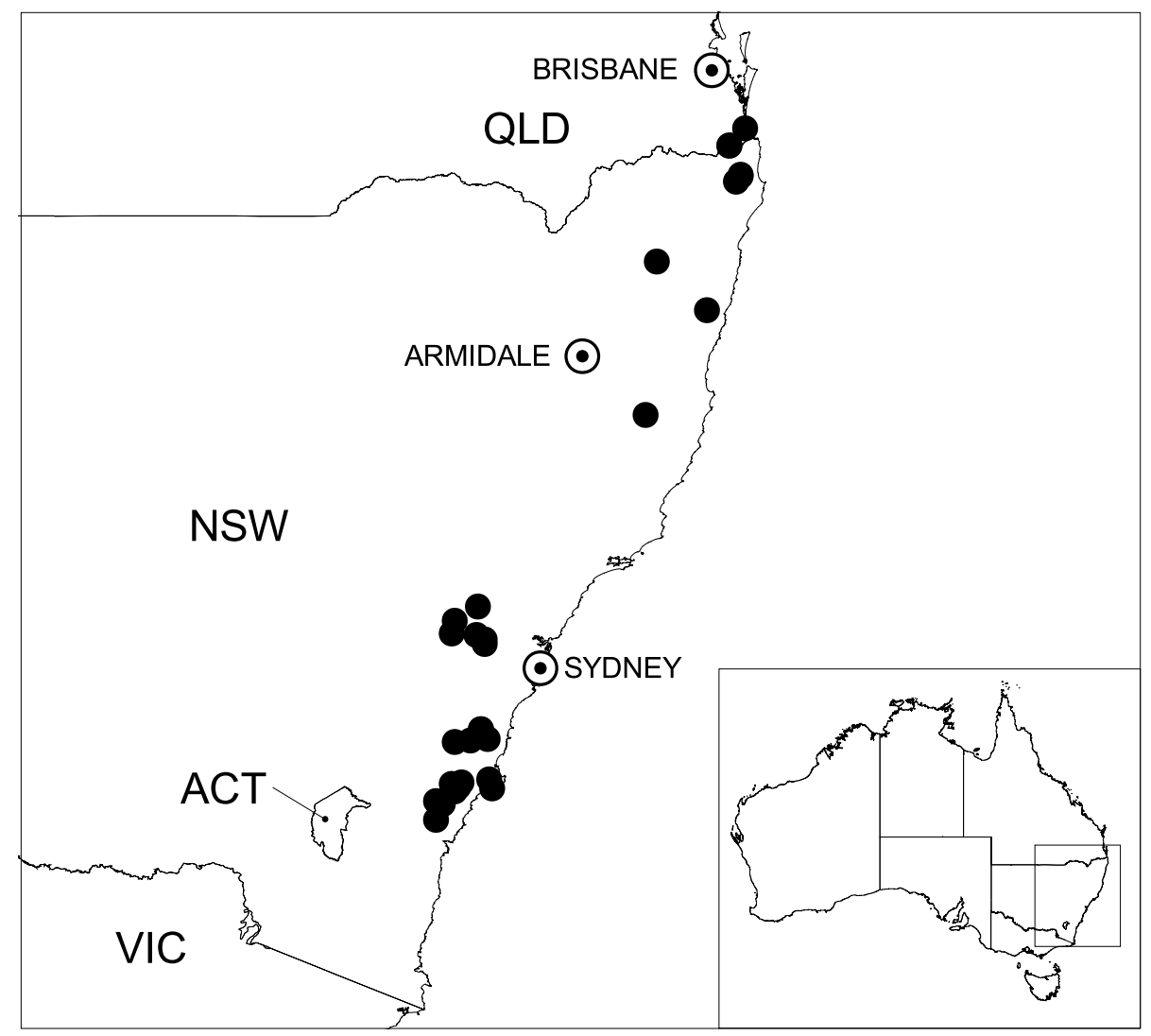

Fig. 2. Distribution of Viola silicestris 
There are three main centres of distribution - from the northern Budawang Ranges and Jervis Bay to Bundanoon and Robertson, in the Blue Mountains from Bowen Mountain to the Newnes Plateau, and in northern New South Wales and south-eastern Queensland from Werrikimbe National Park to Lamington National Park (Fig. 2).

Viola silicestris is typically found in seasonally moist (but often summer-dry) sites in sclerophyllous, heathy vegetation on acid, sandy soils derived from sandstones or silicarich igneous intrusives, particularly rhyolite but possibly also on related rocks such as porphyries and adamellite. It appears to be absent from better-quality soils derived from non-sandstone sedimentaries, granites etc. (although it may be found on the contact zones where the influence of silica-rich parent materials is high).

Conservation Status: Viola silicestris is a relatively common species with a wide distribution including secure populations in several National Parks. It is not under any known threat.

Notes: Viola silicestris may be distinguished from all other Australian violets by its combination of very broad leaves with \pm even teeth across the apex, concolorous, pale, bluish-violet flowers and (in suitable sites) caulescent habit.

Like other species in section Erpetion, leaves of Viola silicestris are highly plastic and vary greatly depending on their conditions of growth (Fig. 3). Plants growing in exposed positions, such as on track verges and in other areas with high sunlight, have reduced leaves which are much smaller and narrower than leaves from plants growing in more sheltered positions amongst vegetation. It is often possible in the field to find a complete gradation from small, narrow, reduced leaves in exposed positions to large, broad, typical leaves in adjacent sheltered sites. Most herbarium specimens, however, fail to represent such local variation adequately. This is a problem throughout the
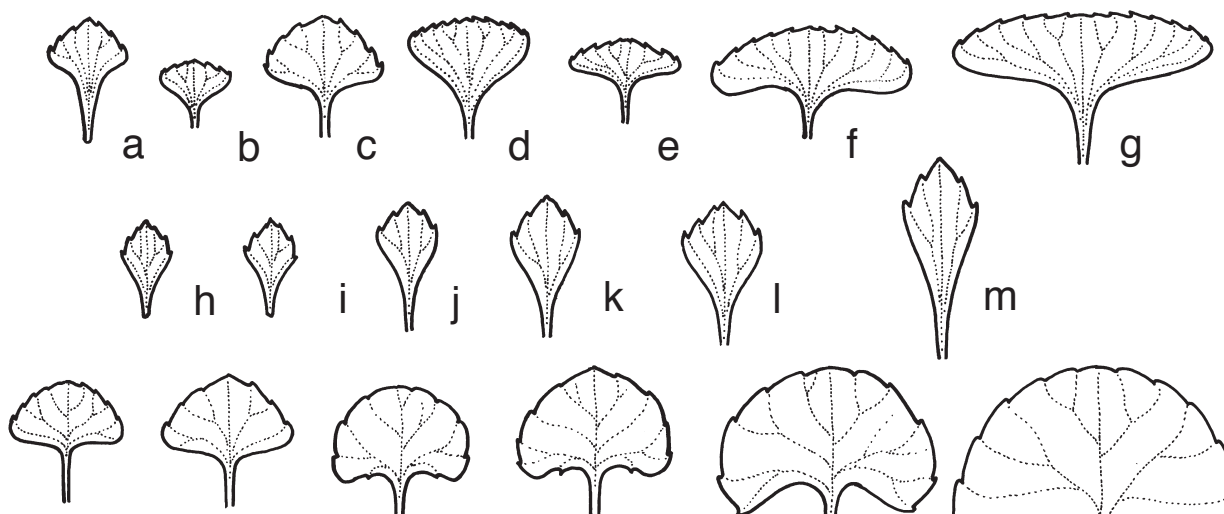

$\mathrm{n}$
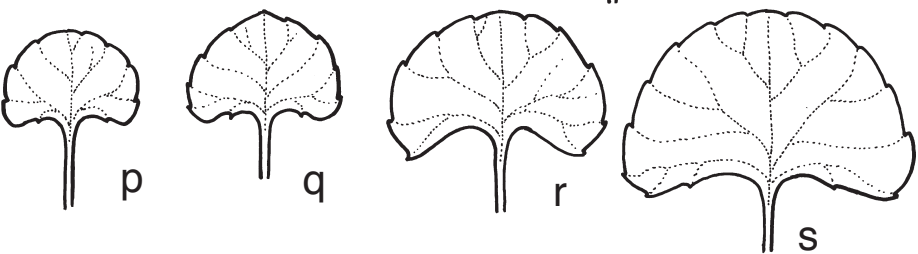

Fig. 3. Range of leaf shapes in three species of Viola $\times 1$. a-g, Viola silicestris; $\mathbf{h}-\mathbf{m}$, V. sieberiana (Sydney population); n-s, V. hederacea s.s. Leaves to the left are from exposed plants with small leaves, leaves to the right are from sheltered plants with fully expressed leaf shapes. 
section, with reduced leaves of all species converging in shape (e.g. Fig. 3c cf Fig. 3o), while fully developed leaves from sheltered sites are usually highly distinctive.

Specimens of Viola silicestris with small leaves have often been placed in V. sieberiana, while specimens with broad leaves have generally been placed in $V$. hederacea sens. lat., largely because the broad leaves rule out $V$. sieberiana and $V$. hederacea has been incorrectly regarded as highly polymorphic. Specimens with intermediate leaves (e.g. NSW522386, NSW522398) have sometimes been regarded as hybrids between Viola hederacea and $V$. sieberiana. There is no evidence that such hybrids exist.

Leaves of Viola sieberiana and V. silicestris differ in that the former are always narrowly spathulate, even in sheltered sites (see Fig. $2 \mathrm{~h}-\mathrm{m}$ ) and have an acute terminal tooth that is distinctly larger than the lateral teeth, whereas even reduced leaves of $V$. silicestris are generally more or less flat-topped with the central tooth no larger than the lateral teeth. Leaves of Viola hederacea differ from both species in being \pm semicircular, at least when fully developed (Fig. 3n-s).

Flowers of Viola silicestris and V. sieberiana are similar in shape, size and colour; together, flowers of these two species are very different from any other species in section Erpetion. They are usually concolorous pale bluish-violet, without distinct white tips to the petals. The anterior petal is narrowly oblong, with a very small green blotch at the base, a whitish region traversed by pale bluish veins in the lower third or half, grading to a concolorous pale bluish-violet apex. In contrast, $V$. hederacea and most other species (with the exception of the very small-flowered $V$. fuscoviolacea and $V$. cleistogamoides) have broader anterior petals with a large green blotch at the base, a pale to bright violet middle section, and a distinct and often sharply contrasting white apex.

Viola silicestris plants often develop a caulescent growth habit when growing in sheltered sites amongst other vegetation, with elongate, weakly erect, scrambling aerial stems to $30 \mathrm{~cm}$ high and scattered leaves. Plants in exposed sites have contracted stems and fasciculate leaves. Viola hederacea and V. sieberiana, by contrast, never develop such a habit, even when growing amongst dense vegetation.

As with other species in the Viola hederacea species complex, it is not unusual to find $V$. silicestris growing allopatrically with other species. It has been found growing more or less intermingled with $V$. hederacea near Robertson, NSW, and with V. sieberiana and $V$. fuscoviolacea near Clarence. In such situations, V. silicestris is usually found in drier sites on poorer, sandier soils. No hybrids between $V$. silicestris and any other species have been seen.

Viola silicestris was included in the key to known Australian species in section Erpetion (Thiele \& Prober 2003) as Viola sp. nov. A. It appears to correspond with Viola hederacea forma A of James (1990), although specimens at NSW have also been annotated as formas B, C and D.

Morphologically, Viola silicestris appears to be most closely related to Viola sieberiana. However, relationships in section Erpetion are largely unknown, and will probably require DNA sequence data and chromosome counts to elucidate.

Selected specimens examined: New South Wales: Northern Tablelands: About $0.5 \mathrm{~km}$ along Minyon Falls walking track, Whian Whian State Forest, 5 Oct 1987, R. Johnstone 57 (NSW209787); Gibberagunyah Mountain, Whian Whian State Forest, Sep 1967, W.T. Jones 3630 (CANB210906); Peach Mountain, Whian Whian State Forest, 15 miles N of Lismore, 3 Nov 
1967, K. Grieves s.n. (NSW137263); Cangai Rd, Cangai Boards Flora Reserve, Dec 2000, NSW NPWS s.n. (NSW444497); Branch of Middle Ck, c. $5 \mathrm{~km}$ NE of Glenreagh, Sherwood Nature Reserve, 13 Mar 1997, P. Gilmour 7722 (NSW434270); Grass Tree Swamp, Werrikimbe National Park, 7 Nov 1992, T.A. James 1328 (NSW423018); Central Tablelands: Nayook Ck, Deep Pass east of Glow Worm Tunnel Rd, Newnes Plateau, Wollemi National Park, 13 Jan 1993, P. Hind 6579 (NSW362405); 14.2 km WNW along Culoul Range Rd towards Colo River, 8 Apr 1977, R. Coveny 9222 (NSW522386); 1.5 km from Bilpin along Mountain Lagoon Rd, 1 Nov 1988, P. Hind 5703 (NSW212907); c. 3 km W of Bell, 25 Feb 1968, R. Coveny s.n. (NSW137315); Track to Tabaraga Rill, c. 2.5 km NW of Bowen Mt, 9 Feb 1988, T.A. James 916 (NSW213497); End of Lt. Bowen Drive, Bowen Mountain Settlement, 9 Mar 1987, T.A. James 867 (NSW196953); Southern Tablelands: Butlers Swamp, Tourist Rd, 7 km N of Robertson, 4 Dec 1992, T.A. James (NSW273260); Bundanoon, 27 Oct 1987, M. O’Neill s.n. (NSW216079); Fitzroy Falls, 30 Nov 1930, F.A. Rodway (NSW137314); 3.6 mls. [5.5 km] from The Jumps turnoff toward Tomerong Nerriga Rd, 12 Nov 1972, M. McMillan 72/87 (CBG50924); 4 km NNE of Mount Tianjara, 2 May 1981, K. Paijmans 3980 (CANB333663); Boolijah Creek, ca 4 km ESE of Sassafras, 15 Oct 1982, L.G. Adams \& R. Pankhurst 3897 (CANB376712); c. 4 miles SW of Corang Peak, Budawang Range, 2 Feb 1974, T.G. Hartley14243 (CANB245755); Tianjara Falls, near Nerriga, 1961, Walker ANU1032 (CANB122254); 10 miles [16 km] S of Sassafras, 24 Oct 1965, T. \& J. Whaite s.n. (NSW522398); The Castle, Northern Budawang Range, 31 Jan 1998, I.R. Telford 12381 (CBG9800212); $4.3 \mathrm{~km}$ E of Tianjara Falls along Turpentine Road to the north, 27 Oct 1988, S. Donaldson 32 (CBG8803775); South Coast: Currowan State Forest: ca 18 km NNW of Nelligen, 8 Mar 1973, L.G. Adams 3138 (CANB381723); Huskisson, Jervis Bay, 13 Sep 1931, F.A. Rodway 507 (NSW137280); 400 m along Stoney Creek Road heading towards Steamers Beach, 29 Sep 1993, M. Kennedy 587 (NSW277654). Queensland: Daves Creek Country, Binna Burra, 23 Nov 1961, R. Jones s.n. (AQ478594); Lamington National Park, c. $3 / 4$ mile [1.2 km] towards Binna Burra from Coomera Falls on the Coomera Track, 15 Jan 1960, R. Schodde 1153 (AQ115410); Upper Tallebudgera Creek, Dec 1917, C.T. White s.n. (AQ115411).

\section{Acknowledgments}

We would like to thank the directors and staff of BRI, CANB, MEL, NSW and AD for access to their collections, Rob Price and Alan Fairley for assistance with field work, and Laurie Adams for discussions on Viola and for the Latin diagnosis. Chris Allen is thanked for his work on the distribution map.

\section{References}

James TA (1990) Violaceae. Pp. 435-441 in Harden GJ (ed.) Flora of New South Wales, vol. 1. (New South Wales University Press: Kensington)

Thiele KR \& Prober SM (2003) Two new species and a new hybrid in the Viola hederacea species complex. Muelleria 18: 7-25.

Manuscript received 22 August 2005, accepted 24 November 2005 